\title{
Milling with ceramic inserts of austempered ductile iron (ADI): process conditions and performance
}

\author{
L. N. López de Lacalle ${ }^{1} \cdot$ A. Fernández Valdivielso ${ }^{1} \cdot$ F. J. Amigo ${ }^{1} \cdot$ L. Sastoque $^{1}$
}

Received: 17 May 2020 / Accepted: 11 August 2020 / Published online: 17 August 2020

(C) Springer-Verlag London Ltd., part of Springer Nature 2020

\begin{abstract}
In the work here presented, the high performance of ceramic insert tools in milling of ADI 1000 iron casting is analyzed. Austempered ductile irons (ADI) are ductile iron castings with strength and mechanical properties enhanced after specific heat treatment, achieving $1000 \mathrm{MPa}$ or even more. Sintered carbide tools are state of the art in many industrial applications, including iron casting machining, but ceramic inserts are a feasible and promising option since cutting speed can be improved by 5 or even 10 times. A complete testing campaign was performed, starting with coated sintered carbides and aiming at the use of whisker reinforced $\mathrm{Al}_{2} \mathrm{O}_{3}$ ceramics and $\mathrm{Si}_{3} \mathrm{~N}_{4}$ tools. The two most important conclusions are as follows: firstly, that the milling type socalled up-milling (or conventional) is more recommended than down-milling, also known as climb milling, and secondly, that dry machining enhances ceramics performance in comparison with using emulsion coolants (oil in water). Finally, results regarding economic aspects were analyzed based on the tools cost-performance ratio.
\end{abstract}

Keywords ADI $\cdot$ Ductile iron $\cdot$ Milling $\cdot$ Machining $\cdot$ Ceramic tools

\section{Introduction}

Ductile cast iron, also known as nodular cast iron or spheroidal graphite cast iron, was developed and patented around 1948. Graphite spheroids in metal matrix, different from graphite layers of gray casts, lead to castings with superior characteristics. Thus, ductile casting was quickly introduced in industrial designs to make lightweight components $[1,2]$. Afterward, ADI (austempered ductile iron) castings represented a new evolution step. In ADI, graphite still appears spheroidal, but the big difference lies in the rest of the microstructure $(\mathrm{Fe}-\mathrm{C})$, which forms the so-called ausferrite. Hence, the ADI casting 5-stage heat treatment (heating, time, quenching, austempering, and cooling) causes a matrix structure, in which the acicular ferrite retains the carbon-stabilized austenite. So after this heat treatment so-called austempering, the ausferrite microstructure grows and develops. The austempering

L. N. López de Lacalle

norberto.lzlacalle@ehu.eus

1 Department of Mechanical Engineering, Aeronautics Advanced Manufacturing Center (CFAA), Faculty of Engineering of Bilbao, Alameda de Urquijo s/n, 48013 Bilbao, Spain temperature determines the casting microstructure and its mechanical properties, resulting in different ADI grades.

The understanding and control of heat treatment led to the introduction of ADI castings in a variety of industrial sectors. This material was and is increasingly demanded by engineers in terms of strength, wear, or fatigue resistance. ADI mechanical properties are superior to pearlite ductile castings, which maximum ultimate strength is around $700 \mathrm{MPa}$ (standards EN-GJS-700-2, ASTM 100/70/03). Thus, in ADI, ultimate strength ranges from 900 to $1400 \mathrm{MPa}$, being the grades ranging between 800 and 1100, the most used because they keep good ductility, just the contrary of those with the highest strength and hardness 1400 and 1600 only used for knives and shearing tools. Standards for ADI are ISO 17804-2005 (see Table 1), EN1564, ASTM A897M. Some examples of ADI applications are agricultural equipment, construction, gears, components for heavy trucks and trailers, busses, luxury cars, mine equipment, railroad, and power generation components.

At the view of Table 1, ADI tensile and yield strength are twice medium ductile iron (400 MPa). In addition, fatigue strength is $35-50 \%$ higher, and it can be improved by mechanical treatments such as roll or ball burnishing, by shot peening or filet rolling. ADI micro hardness is higher than steels with comparable hardness. 
Table 1 ADI standard in ISO 17804

\begin{tabular}{llllll}
\hline Symbolic definition & ISO & $\begin{array}{l}\text { Tensile } \\
\text { strength } \\
(\mathrm{MPa})\end{array}$ & $\begin{array}{l}0.2 \% \\
\text { Strength } \\
(\mathrm{MPa})\end{array}$ & $\begin{array}{l}\text { Elongation } \\
\text { A5(\% min) } \\
\text { Lo }=5 x \mathrm{xD}\end{array}$ & $\begin{array}{l}\text { Hardness } \\
\text { HB }\end{array}$ \\
\hline ADI 800 & ISO17804/JS/800-10 & 800 & 500 & 10 & $250-310$ \\
ADI 900 & ISO 17804/JS/900-8 & 900 & 600 & 8 & $280-340$ \\
ADI 1050 & ISO 17804/JS/1050-6 & 1050 & 700 & 6 & $320-380$ \\
ADI 1200 & ISO 17804/JS/1200-3 & 1200 & 850 & 3 & $340-420$ \\
ADI 1400 & ISO 17804/JS/1400-1 & 1400 & 1100 & 1 & $380-480$ \\
ADI 1400 & ISO17804/JS/HBW400 & 1400 & 1100 & 1 & Min. 400 \\
ADI 1600 & ISO17804/JS/HBW450 & 1600 & 1300 & - & Min. 450 \\
\hline
\end{tabular}

Regarding machinability, ADI grades contain more hard particles dispersed into microstructure than ductile ones, with the consequent abrasion effect on cutting tools. On the one hand, high thermal and mechanical loads lead to concentrate crater wear near tool cutting edges. On the other hand, strain hardening during chip formation results in surface hardening after each tool pass and, therefore, a trend to cause notch wear at the depth of cut line in successive passes. This fact is common in austenitic metal alloys, such as stainless steels and nickel alloys, and it is related to the FCC (face-centered cubic) structure of the austenite phase. Turning and other operations were described by Klocke et al. [3, 4] and extended to the use of ceramic inserts [5]. Drilling was investigated by Meena and El Mansori [6, 7], and threading by Elosegui et al. [8], who defined the best PVD coatings for the task; in this work, cutting edge preparation before and after coating processes was defined as the key trick of the trade, as it was also shown by Fernandez et al. [9, 10].

Cobalt and tungsten are highly critical raw materials from an economic perspective; carbide tools account for $60 \%$ of the worldwide use of tungsten (W). So, other alternatives are welcome as the ceramic tools are. Milling with ceramics typically runs at 5 to 10 times the speed of carbide tools but at lower feed rates $(\sim 0.1 \mathrm{~mm} /$ tooth $)$. The milling process is cooler than turning, due to the intermittent cutting nature of milling, whereas turning is a continuous process. For this reason, speeds of $400-800 \mathrm{~m} / \mathrm{min}$ are possible in milling compared with the $200-300 \mathrm{~m} / \mathrm{min}$ in turning. Tool life in ADI is reduced $40 \%$ with respect to ductile iron, and cutting forces are approximately $30-40 \%$ higher. ADI is a short-chipping material with good chip control. Specific cutting force ranges from 790 to $1350 \mathrm{~N} / \mathrm{mm}^{2}$, but in some previous tests performed by authors, values were between 1600 and $1800 \mathrm{~N} / \mathrm{mm}^{2}$ for ADI 1000 and 1200 , respectively.

Sinlah [11] studied the machinability of ADI grades 900, 1050 , and 1200. Face milling operations were carried out on 25-mm thick plates with a three tooth, $80-\mathrm{mm}$ face milling tool: chip load of $0.08 \mathrm{~mm} /$ tooth and depth of cut of $1 \mathrm{~mm}$, with varying cutting speed of $120-360 \mathrm{~m} / \mathrm{min}, 240-480$ $\mathrm{m} / \mathrm{min}$, and $240-480 \mathrm{~m} / \mathrm{min}$ for grades 1200,1050 , and 900 , respectively.

Priarone et al. [12] worked on milling ADI 1200. Tests were performed using uncoated and titanium aluminum nitride (TiAlN) or titanium carbo-nitride (TiCN)-coated cutting inserts, obtained from both recycled and new tungsten carbide-cobalt (WC-Co)-based materials.

Another typical concern in iron casting and heat treatments is that the entire component mass was transformed, reaching similar metal metallurgical structures and mechanical properties as well. Metal composition and heat treatment conditions both affect the size of section that can be fully transformed [13]. There are not only metallurgical changes but additional concerns about residual stresses that can affect part shape after machining [14]. In the work here presented, several coupons were extracted per testpiece to check the casting variability, but the uniformity of both graphite (dispersion and nodule size) and ausferrite was excellent in all the cases.

Regarding new cutting tool grades, high-chromium white cast irons (HCCI) were studied in longitudinal turning with binderless $\mathrm{cBN}(\mathrm{bcBN}$ ) and high $\mathrm{cBN}$ (hcBN) tools by Gutnichenko et al. [15], and a tool protection layer on the tool-chip interface was found to be responsible for the improved dynamic stability. In turning of casting type CGI (compact graphite iron), different PVD based on AlTiN were tested, finding that built-up edge formation, combined with abrasive and adhesive wear, suffered at moderate cutting speeds [16]. Remarkably, CGI is softer than any ADI grade.

Finally, the economic view of milling process is a key to increase the use of ADI in high-added value components. Several developments were proposed [17] since the Taylor's equation for Tool Life Expectancy. The equation was formulated by F. W. Taylor in 1906, which provides a good approximation of tool life for varying cutting speed $v_{c}$. In the $1980 \mathrm{~s}$, B. Colding [18] proposed another curve based on empirical curve adjustments between tool life and cutting data, with several improvements proposed by Lindström [19] and others [20]. The use of CPR (cost-performance ratio) refers to tool performance divided by price; so it could be useful for 
comparison of cutting tools such as sintered carbide and ceramics, the latter double expensive than the former but much more productive as it will be showed in the following sections.

Regarding process modeling, finite element method could be promising as it is in other metal alloy cases, so it was defined in [21-23] for titanium and other ductile metal alloys. However, there is a lack of data about Johnson \& Cook material equation parameters for $\mathrm{ADI}$, and so the point is still open for researching. In addition, each ADI grade would imply different testing and material law parameters.

The work here presented will start defining a solution with coated sintered carbide, in order to compare with the use of ceramic tools in milling.

\section{Performance with coated sintered carbide tools}

In the present work, testing was performed on ADI 1000 grade; this grade is the objective in many industrial applications in order to achieve more strength with the same and even lower piece thicknesses. An example of this purpose, the increase in power in windmills implies new designs using ADI in several casings and planet carriers for gearboxes; ADIenhanced strength prevents from penalizing transmission weight, taking into account that gearboxes are inside windmill nacelles, at $100 \mathrm{~m}$ high in some cases. Gearboxes weight is critical in generators with power over $10 \mathrm{MW}$ and in offshore ones. Otherwise, the hardest ADI grades are not as interesting as ADI 1000, because they are not very ductile as shown in
Table 1. Figure 1 shows the casting structure of testpieces used in this work, showing (i) the graphite nodular shapes (circular dark shapes) and (ii) the matrix ausferrite phase. Testpiece block size was $0.24 \times 0.20 \times 0.18 \mathrm{~m}$, and the size allowed a full heat treatment of all piece body.

Sintered carbide tools are the first option in current milling technology. There are many insert types for face milling, being this operation the most demanded in roughing and semifinishing stages. At this research step, the testing purpose was to define the "base solution" with carbides for ADI 1000 face milling and to define the starting ground for later comparison with ceramics. Carbide tools are used daily in workshops, but ceramics would become a possibility.

Two types of face milling insert tools were chosen, defined in Table 2, in which the main parameter the insert grade was. One was an 8-edge octagonal insert; meanwhile, the other was a square one but with two working faces (so 8-working edges as well). The former was tested in different carbide grades (each carbide grade with a different balance of hardness and toughness), the latter only to check if insert geometry affected results seriously.

Regarding the octagonal inserts, they were wiper style with a secondary cutting edge making this function. Primary cutting edge rake angle was $7^{\circ}$, clearance angle $15^{\circ}$, and main lead angle $45^{\circ}$ (called $K$, the position of primary edge with respect to feed direction). Carbide grades were three, from the hardest to the toughest, showed below; in parenthesis are marked the grades three mechanical characteristics (transverse rupture strength-TRS in MPa, hardness HRA, and Vickers HV30):
Fig. 1 ADI 1000 structure, showing nodular graphite and ausferrite (scales are 200, 100, 40, and $20 \mu \mathrm{m})$

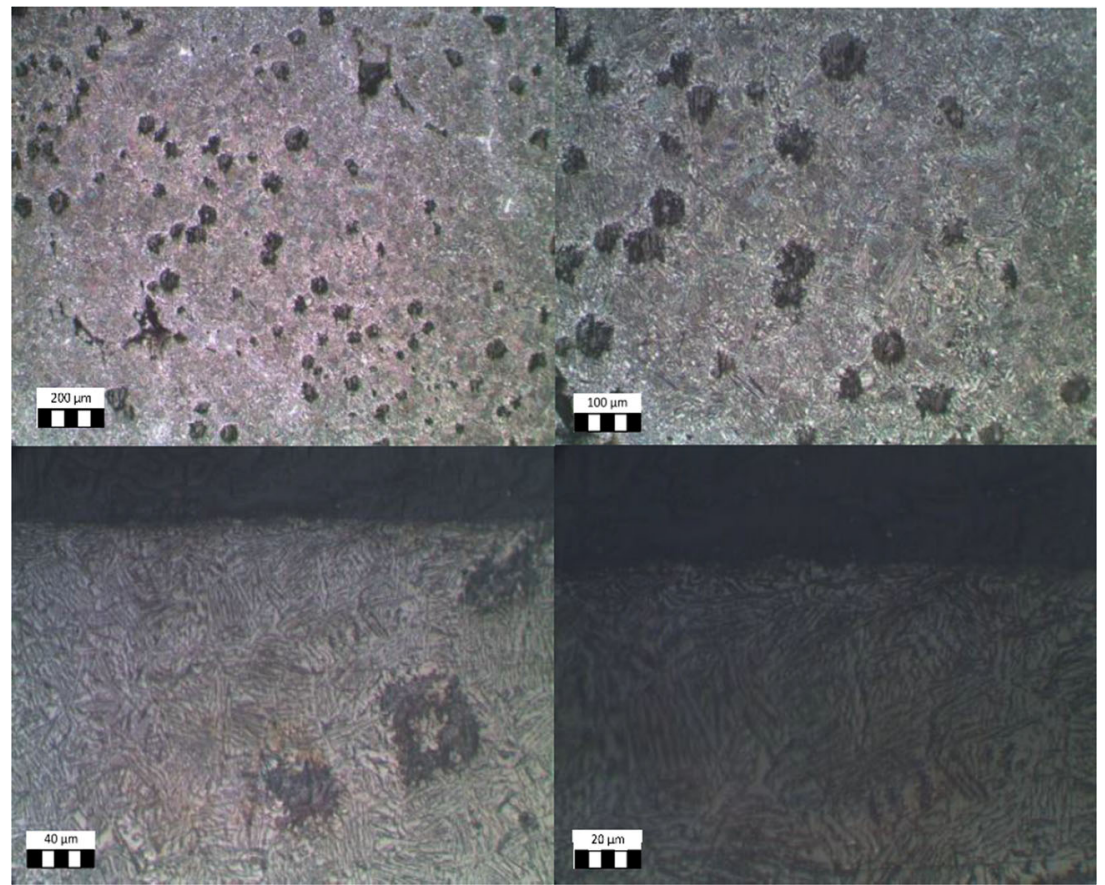


Table 2 Sintered carbide inserts and tools

Type A
Grade A1: $\mathrm{K} 25$, with CVD coating $\mathrm{Al}_{2} \mathrm{O}_{3}$
and TiCN
Grade $\mathrm{A2}: \mathrm{K} 35$, with CVD coating
AlTiN , $\mathrm{Al}_{2} \mathrm{O}_{3}$ and TiN
Grade $\mathrm{A3}_{\mathrm{K}} \mathrm{K} 45 \mathrm{CVD}$ coating of $\mathrm{AlTiN}$
and $\mathrm{Al}_{2} \mathrm{O}_{3}$

- Grade A1: $\mathrm{K} 25$, with CVD coating $\mathrm{Al}_{2} \mathrm{O}_{3}$ y TiCN, this is the hardest grade $(2600,91.5,1520)$.

- Grade A2: K35, with CVD coating AlTiN, $\mathrm{Al}_{2} \mathrm{O}_{3}$ y TiN (2900, 91.1, 1475). Intermediate grade regarding mechanical characteristics.

- Grade A3: K45 CVD coating of AlTiN and $\mathrm{Al}_{2} \mathrm{O}_{3}$ (3000, $89.5,1260)$, this was the toughest one.

Cutting speed $v_{c}$ was $130 \mathrm{~m} / \mathrm{min}, f_{z} 0.18, a_{p} 2 \mathrm{~mm}, a_{e}$ was $34 \mathrm{~mm}$, and tool diameter was $48 \mathrm{~mm}$. With these conditions, the maximum chip thickness in plane $\mathrm{XY}$ was equivalent to feed because $a_{e}$ was larger than tool radius ( $34 \mathrm{~mm}$ is lower than $48 \mathrm{~mm}$, tool radius).

Regarding the second insert type, it was square shape and also a wiper style, primary cutting edge rake angle, $4^{\circ}$, and lead angle $45^{\circ}$. Regarding the milling process, similar cutting parameters to the previous case were applied. The purpose was to confirm whether insert geometry influenced the results dramatically. So, the second carbide tool was:
- Grade B1: $\mathrm{K} 30, \mathrm{CVD}$ coating $\mathrm{Al}_{2} \mathrm{O}_{3}$ on a TiCN,9 microns $(3000,89.9,1350)$. So the grade characteristics were between cases A2-A3. Insert type was 8.8-mm edge length (LE) with $2 \mathrm{~mm}$ of wiper (BS) edge, $13 \mathrm{~mm}$ (IC) (see Table 1).

Regarding cooling, dry milling condition was used, and because iron castings imply lower toughness than steel, so energy caused by deformation in the chip formation process is not as high as in steels; in fact, dry is always the first option in castings. In addition, chips tend to be very small and easily removed by simple air nozzles. Tests were repeated twice, with similar results because wear was gradual flank wear. Five inserts were in the toolholder, so average values in Fig. 2 were of 10 inserts each, and rectangles show dispersion, low dispersion when wear is not high but spreading when tools are damaged.

At the view of results in Fig. 2, the lowest tool wear was reached by the hardest carbide grade with good repeatability. The reason is that ADI is an iron casting, so ductility is lower than steels with equivalent hardness even when its strength is similar, around $1000 \mathrm{MPa}$. So during all the tests, chips were very small with no tendency either to deform or to be gummy. Therefore, the hardest the tool, the best the performance is; Fig. 2 is evident in that conclusion.

Insert B1, coming from another manufacturer, showed the same trend, as presented in Fig. 2, being B1 a very similar carbide and coating to grade A1. So, hard carbide grades with $\mathrm{Al}_{2} \mathrm{O}_{3}$ and TiCN coatings implied the longest tool life, reaching $16 \mathrm{~m}$ with flank wear lower than $0.2 \mathrm{~mm}$ at cutting speed of $130 \mathrm{~m} / \mathrm{min}$ and feed per tooth around $0.2 \mathrm{~mm}$ (Fig. $3)$.

Table 3 shows several pictures of flank wear. In the worst cases at the end of tool life, notch wear also appeared at the
Fig. 2 Effect of cutting tool grade on tool performance (average values of two repetitions and five inserts and deviation)

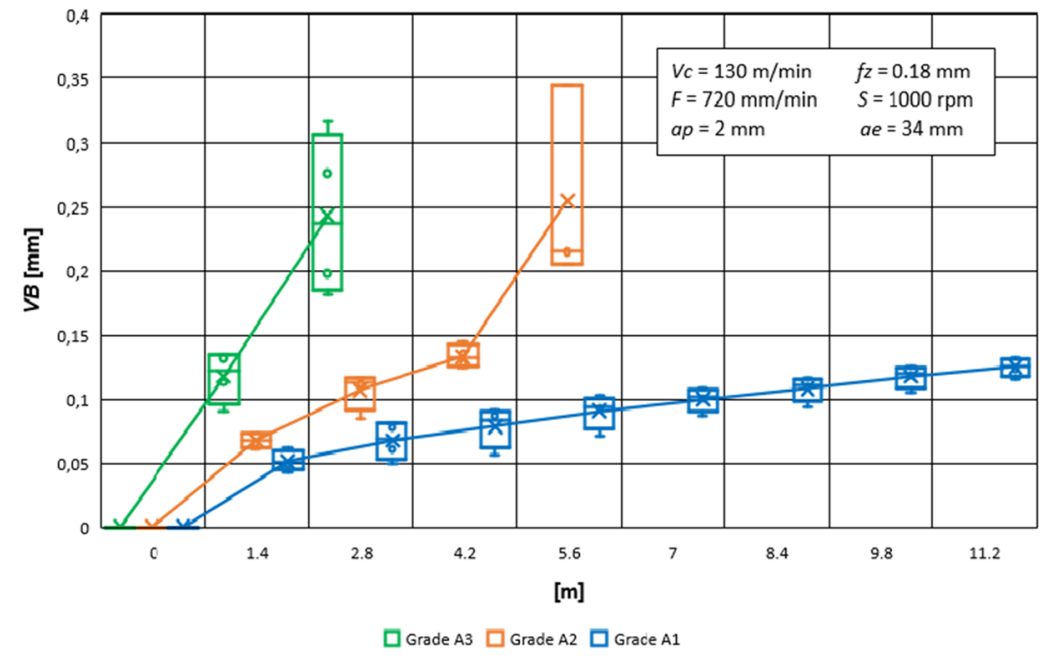


Fig. 3 Type B1 performance (average values of two repetitions and four inserts and deviation)

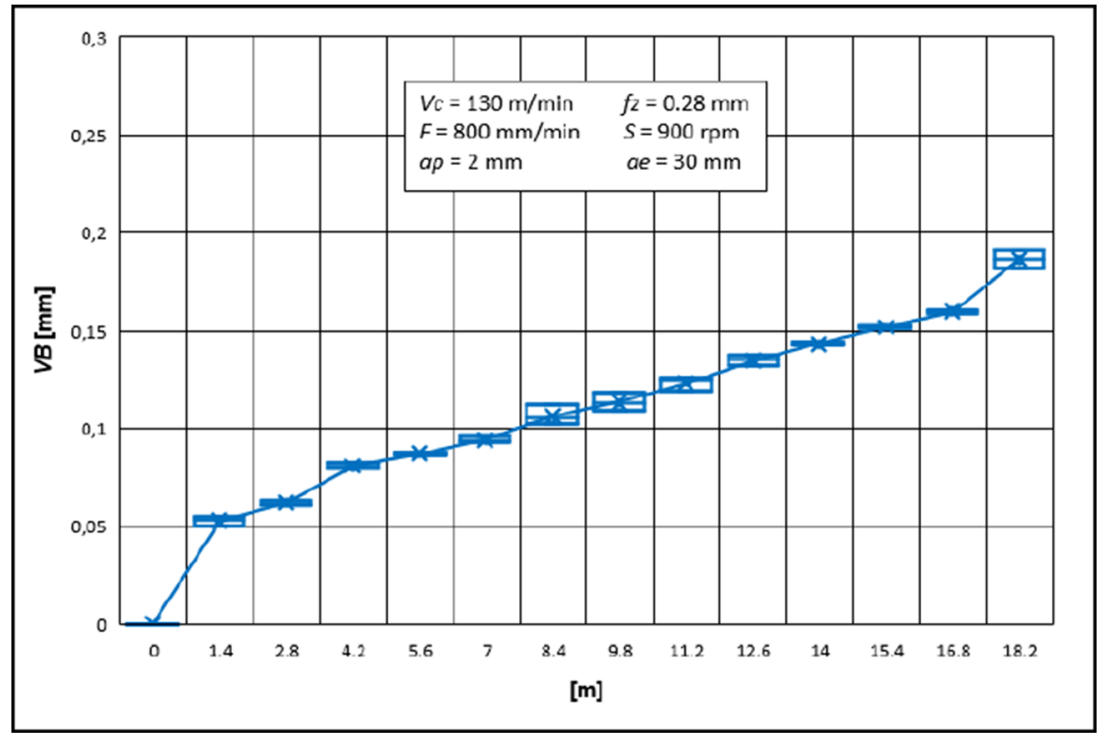

depth of cut line, but until then, flank wear maintained a uniform pattern and linear evolution.

\section{Ceramic inserts}

Ceramic tools are always a possibility to improve productivity with respect to sintered carbide tools but without cost increment. The present work novelty is clear, because the use of ceramics in milling must face two main drawbacks, (i) consecutive hits at tool engagement into material by the interrupted nature of milling process and (ii) thermal shocks coming from the same reason. When using ceramics, the

Table 3 Flank wear at clearance face in several cases (scale is the same in all the cases)

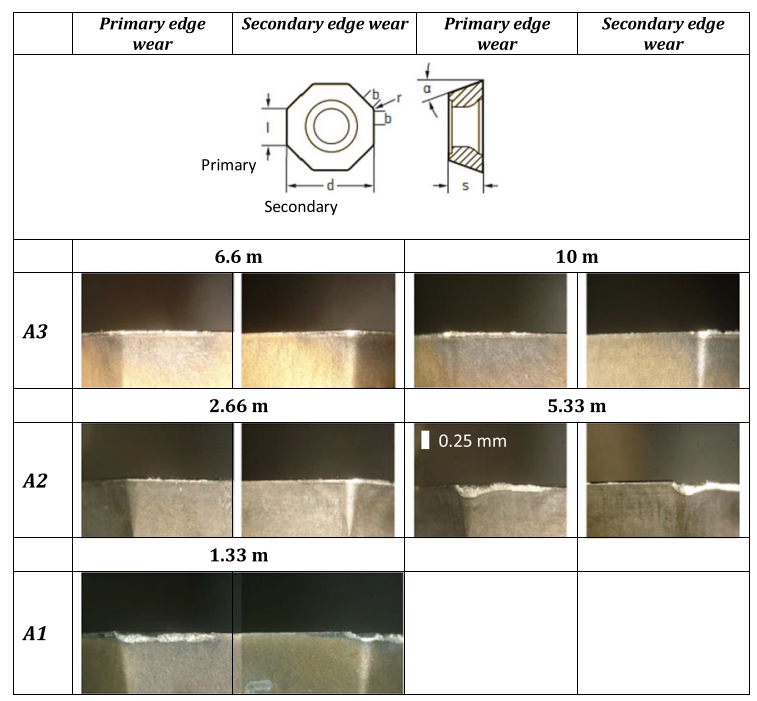

recommendation is preferably run dry, without cutting fluid, to minimize problems with thermal cracks.

\subsection{Tool grades and cutting edge preparation}

Tested ceramics were round inserts (RNGN) in two grades, each one with the same type of edge preparation of chamfering. The chamfering of primary cutting edge implies an increase in toughness, very useful in milling because the interrupted nature of milling implies continuous hits against the cutting edge. Button-type round inserts were $\varnothing 12.7 \mathrm{~mm}$, neutral, and with thickness of $7.94 \mathrm{~mm}$, and so on tool holder geometry leads to a rake angle $-6^{\circ}$.

Toolholder was specially designed and manufactured for holding three round inserts. General rules in milling with ceramics are as follows: (a) select a larger edge preparation (chamfering), (b) reduce feed rate compared with turning, and (c) increase recommended speeds again from turning. Regarding the second rule, feed rate must be reduced with respect to turning on severe interruptions to get more heat into a thinner chip. Ceramic tools are shown in Table 4. Two were the tested grades:

Table 4 Ceramic milling tool and inserts: geometry, wear location, chamfering (edge preparation), and ceramic microstructures

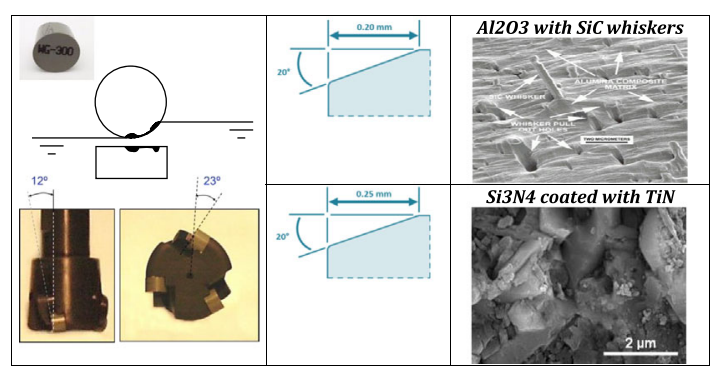


Table 5 Cutting parameters to define milling type

\begin{tabular}{|c|c|c|c|c|c|c|}
\hline $\begin{array}{c}v_{\mathrm{c}} \\
(m / m i n)\end{array}$ & $\begin{array}{c}f_{z} \\
(m m / z)\end{array}$ & $\begin{array}{c}a_{p} \\
(m m)\end{array}$ & $\begin{array}{c}a_{e} \\
(m m)\end{array}$ & $\begin{array}{c}F \\
(\mathrm{~mm} / \mathrm{min})\end{array}$ & $\begin{array}{c}S \\
(\text { r.p.m })\end{array}$ & $z$ \\
\hline 400 & 0.1 & 1.5 & 30 & 1,273 & 4,244 & 3 \\
\hline
\end{tabular}

Down-milling/climb-milling and up-milling/conventional

- Ceramic $\mathrm{Cl}: \mathrm{Al}_{2} \mathrm{O}_{3}$ reinforced by whiskers of $\mathrm{SiC}$ in a homogenous but amorphous matrix. Whisker length is less than $100 \mu \mathrm{m}$. Matrix improves toughness to withstand interrupted cutting. Edge preparation was a chamfering $20^{\circ}, 0.2 \mathrm{~mm}$ from the cutting edge.

- Ceramic $\mathrm{C} 2: \mathrm{Si}_{3} \mathrm{~N}_{4}$ ceramic coated by TiN. Their elongated crystals form a self-reinforced material with high toughness. The TiN coating reduces friction. Edge preparation was a chamfering $20^{\circ}, 0.25 \mathrm{~mm}$ from the cutting edge, so little bigger than $\mathrm{C} 1$ case.

\subsection{Type of cutting: up-milling vs. down-milling}

Ceramic tools are more fragile than sintered carbide ones, so the choice between down-milling/climb-milling and up-milling/conventional milling was the first research target. The former type is usually the first option in modern machining, because machines are both stiff and precise enough, and therefore to cut from maximum to zero chip section is not a problem. On the other hand, the latter was the leading choice 40 years ago, when machines stiffness and axes ball-screw errors were not high, and the name conventional comes from that fact. Ceramic 1 and 2 cutting parameters are defined in Table 5, at this research stage, cutting speed value was very conservative.

At the view of Fig. 4, results clearly showed that up-milling showed longer tool life because of the lower flank wear. The reason is that in up-milling, it starts with minimum chip thickness (zero) reaching the value $f_{z} \operatorname{sen} \theta$, being in this case $a_{p}$ $2 \mathrm{~mm}$ and insert diameter $12.7 \mathrm{~mm}$, and the engagement angle is approx. $48^{\circ}$, so maximal chip thickness was $0.075 \mathrm{~mm}$.

The observed results can be against the general recommendations of tool manufacturers, since general rules in ceramics are usually given for nickel or ductile metal alloys milling, in which the use of climb milling technique avoids high heat in the thin section of the chip which encourages chip welding and provoke re-cutting of chips, which in turn reduces tool life. However, in ADI 1000 case, material ductility and the related deformation energy are lower in comparison with ductile nickel or steels, so the reduction of heat at insert engagement is more important. Sparks in up-milling do not appear, and they are the most visible aspect in climb milling.

\subsection{Emulsion coolant vs. dry condition}

Both ceramic insert types were tested in dry (no coolant [24]) and wet conditions, using in the latter emulsion of oil (5-8\%) in water, and oil was amine-free that works in the low $\mathrm{pH}-$ layers of 7.5 to 8.5 . Up-milling case was used, because results were much better in the previous stage, as explained in the above section. Tests were carried out at $700 \mathrm{~m} / \mathrm{min}$, and feed was $0.1 \mathrm{~mm}$ per tooth, with axial depth of cut $1.5 \mathrm{~mm}$ and radial width of cut $30 \mathrm{~mm}$. Results are gathered in Fig. 5, and values are average of two repetitions and three inserts, with less than $3.5 \%$ of divergence.
Fig. 4 Results of down-milling vs. up-milling, average and deviation values

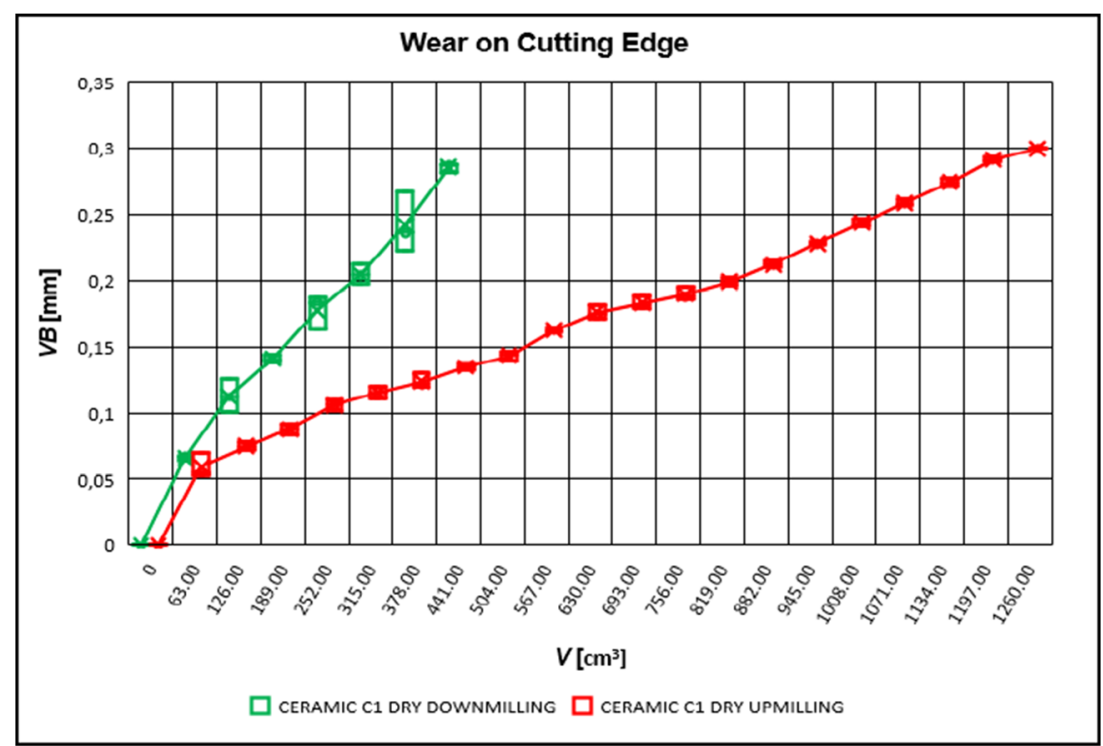


Fig. 5 Tool wear VB along machined volume $\left(\mathrm{cm}^{3}\right)$ at very high speed $\mathrm{v}_{\mathrm{c}} 700 \mathrm{~m} / \mathrm{min}$

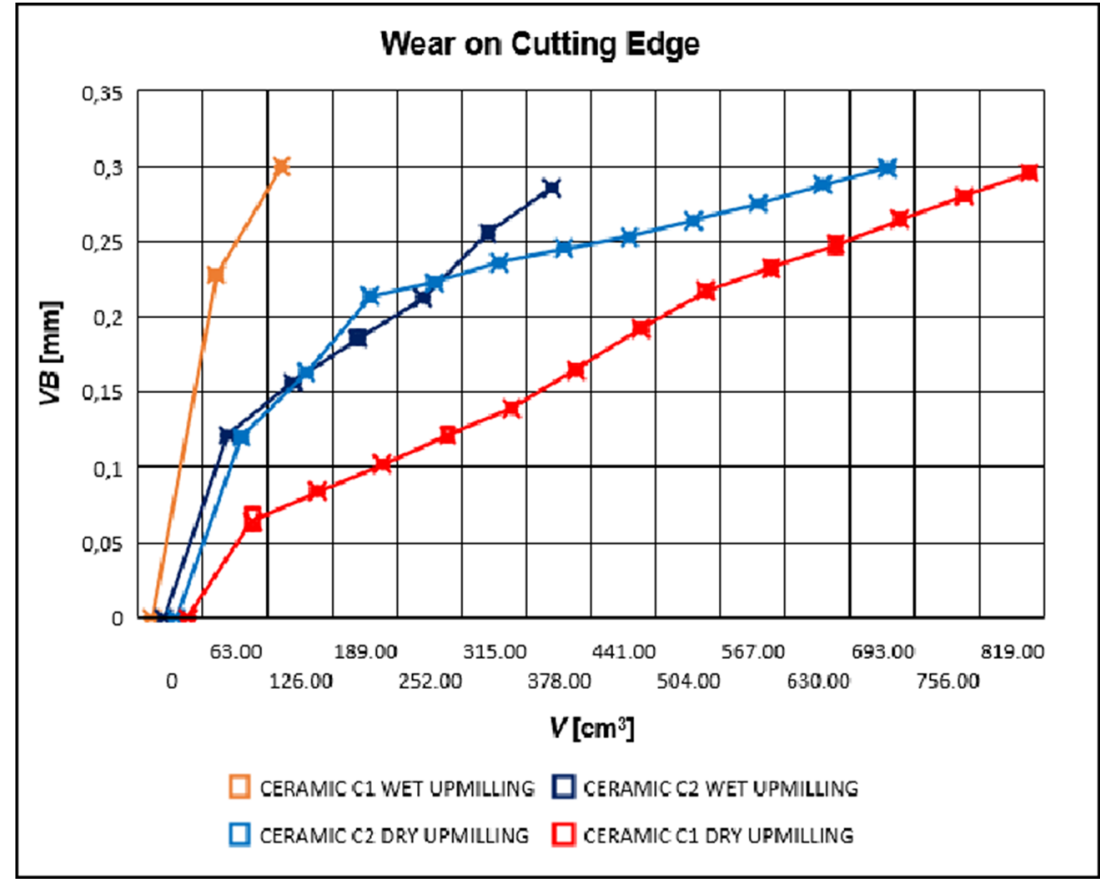

The best results were always in dry conditions. The reason is that milling is an interrupted cutting process, so cooling of ceramic inserts induces a constant thermal shock. The heatresistant ceramics can work up to $2000{ }^{\circ} \mathrm{C}$. Taking into account the high cutting speed of $700 \mathrm{~m} / \mathrm{min}$, machining heat is removed by the chips. Using up-milling implies that the big amount of heat is removed from the cutting zone, near adiabatic condition, i.e., all heat is removed by chip evacuation in line with the historical patent about high-speed machining proposed by C. J Salomon of 1929.

Wear patterns of four cases are shown in Table 6. Flank wear is the main one; however, in those results using cooling tool, edge microchipping was typically found.

Regarding the different ceramic performances, both two are similar at high speed of $700 \mathrm{~m} / \mathrm{min}$, but whisker ceramic reinforced ones were a little better; therefore, the choice between one and the other would be based on economic considerations.

\section{Economic comparison}

At the view of previous sections, ceramic tools presented the highest productivity measured as MMR (material removal rate), i.e., the amount of iron casting removed per time unit. On the other hand, insert cost was divided by the number of cutting edges used per unit, normalized to eight edges per insert. Regarding insert costs, if carbide is defined as $\mathrm{P}$, ceramic inserts prices range from 2 to $3 \mathrm{P}$ ( $\mathrm{P}$ can be $2-3$ euros in the year 2020).
Another cost in the balance is the machine tool hour cost, which depends on machine size, companies' pay-off policy, machine depreciation with time, and others. Figure 6 shows an analysis based on the use of ceramic inserts along with the best carbide insert resulted in the testing campaign, for two average machine costs, between small ones and those bigger and more expensive, used, for instance, in the windmill sector. ADI can be used in small components machined in small- or mediumsized machines known as machining centers. And ADI can be used in gearboxes and heavy-duty equipment components manufactured either in machines known as vertical lathes with milling capabilities or in big milling machines. If small ones

Table 6 Wear patterns for both ceramic grades in dry and wet conditions
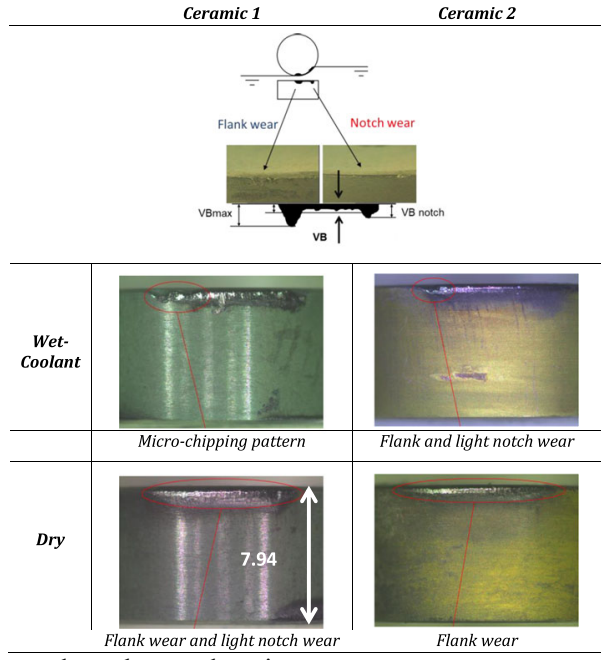

Flank wear and notch wear locations 
Fig. 6 The total cost of manufacturing for ceramic inserts comparing with carbide

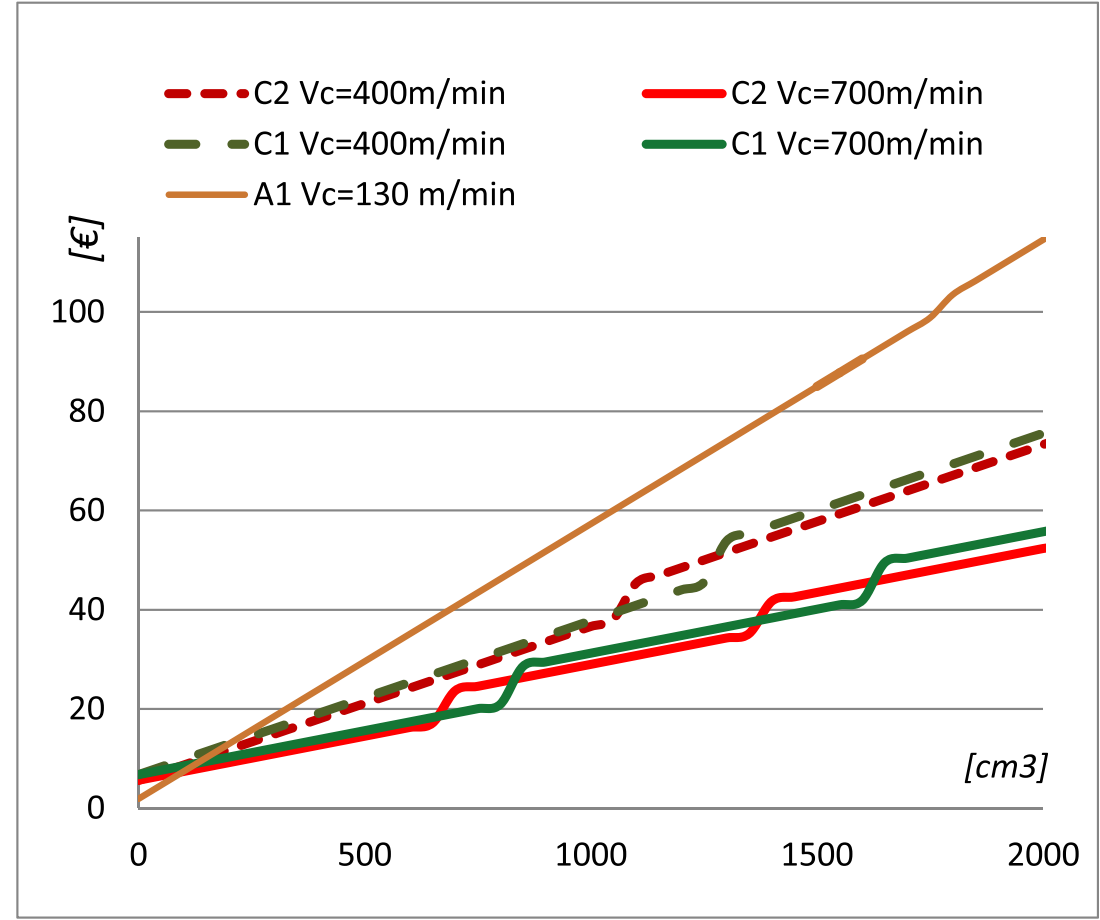

cost is defined as MT, the biggest ones are around 3MT cost per hour (MT could be 40 euros in 2020). The latter is the case used in Fig. 6.

At the view of Fig. 6, both ceramics are very similar; $\mathrm{C} 1$ could be very slightest better in longer results, and A1 is the solution with carbide tools. In this case and other with machines even more expensive, ceramic inserts are a real option applying high cutting speed. The higher the machine cost, the more interesting is the application of ceramic inserts in actual production. CPR (cost-performance ratio) defined as performance regarding insert cost is three times in ceramics than carbide.

\section{Conclusions}

At the view of testing results using carbide and two types of ceramic inserts, several conclusions can be highlighted:

1- Regarding ADI 1000, milling with carbide tools, using grades with the highest hardness, type K45, micro grain WC, with A12O3, and TiCN coatings implied the longest tool life. They reached $16 \mathrm{~m}$ with wear lower than $0.2 \mathrm{~mm}$ at cutting speed of $130 \mathrm{~m} / \mathrm{min}$ and feed per tooth around $0.2 \mathrm{~mm}$

2- Ceramic inserts for milling is a feasible approach. Usual concerns related with ceramic fragility under the consecutive hits originated by the milling interrupted process nature were overtaken. Three main conclusions were found out:

a. Up-milling presented better performance than climb milling.

b. Dry condition and high speed $(700 \mathrm{~m} / \mathrm{min})$ are the optimal conditions, reaching $800 \mathrm{~cm}^{3}$ with VB 0.3 $\mathrm{mm}$.

c. Whisker reinforced alumina grade presented the best performance regarding tool life/productivity ratio. The reinforced ceramic can withstand the continuous hits originated by the tool entrance/output from workpieces that happen in milling.

3- Under an economic perspective, ceramic tools can be a right choice in modern workshops for ADI milling, taking into consideration the cost of ceramics with respect to carbides.

Future research will focus on improving milling productivity (increasing feed and cutting speed), including machined surface integrity [14] study and residual stresses in big cast parts after heat treatment.

Acknowledgments Authors are grateful to the Basque government group IT IT1337-19 and Spanish Ministry Minecor REF DPI2016-74845-R and project PID2019-109340RB-I00 in testing method and RETOS RTC2017-6039-5 in casting research. Thanks to the project management group for helping us with the general project guiding procedure.

Thanks are addressed to all people staying patiently at home in this virus crisis and to medicine people taking care of other people and fighting COVID-19. 


\section{References}

1. Keough J, Hayrynen K, Pioszak G (2010) Designing with austempered ductile iron (ADI). AFS Proc 1-15. American Foundry Society, Schaumburg

2. Sahin Y, Kilicli V, Ozer M, Erdogan M (2010) Comparison of, abrasive wear behavior of ductile iron with different dual matrix structures. Wear 268:153-165. https://doi.org/10.1016/j.wear. 2009.07.008

3. Klocke F, Klöpper C, Lung D, Essig C (2007) Fundamental wear mechanisms when machining austempered ductile iron (ADI). CIRP Ann-Manuf Technol 56:73-76. https://doi.org/10.1016/j. cirp.2007.05.020

4. Klocke F, Arft M, Lung D (2010) Material-related aspects of the machinability of austempered ductile iron. Prod Eng 4:433-441. https://doi.org/10.1007/s11740-010-0227-4

5. Aslantas K, Ucun I (2009) The performance of ceramic and cermet cutting tools for the machining of austempered ductile iron. Int $\mathrm{J}$ Adv Manuf Technol 41:642-650. https://doi.org/10.1007/s00170008-1528-z

6. Meena A, El Mansori M (2013) Specific cutting force, tool wear and chip morphology characteristics during dry drilling of austempered ductile iron (ADI). Int J Adv Manuf Technol 69: 2833-2841. https://doi.org/10.1007/s00170-013-5220-6

7. Meena A, El Mansori M (2011) Study of dry and minimum quantity lubrication drilling of novel austempered ductile iron (ADI) for automotive applications. Wear 271:2412-2416. https://doi.org/10. 1016/j.wear.2010.12.022

8. Elosegui I, Alonso U, Lopez de Lacalle LN (2017) PVD coatings for thread tapping of austempered ductile iron. Int J Adv Manuf Technol 91:2663-2672. https://doi.org/10.1007/s00170-016-99638

9. Fernández-Abia AI, Barreiro J, López de Lacalle LN, GonzálezMadruga D (2014) Effect of mechanical pre-treatments in the behavior of nanostructured PVD-coated tools in turning. Int J Adv Manuf Technol 73:1119-1132. https://doi.org/10.1007/s00170014-5844-1

10. Fernández-Abia AI, Barreiro J, Fernández-Larrinoa J, de Lacalle LNL Behaviour of PVD coatings in the turning of austenitic stainless steels. Proc Eng 63:133-141

11. Sinlah A Jr (2014) A study of machinability in milling of austempered ductile iron (ADI) ADI 900, ADI 1050, and ADI 1200 with carbide tools. MSc Thesis - The Pennsylvania State University

12. Priarone PC, Robiglio M, Settineri L (2016) Milling of austempered ductile iron (ADI) with recycled carbide tools. Int J Adv Manuf Technol 82:501-507. https://doi.org/10.1007/s00170-015-7387-5
13. Blackmore PA, Harding RA (1984) The effects of metallurgical process variables on the properties of austempered ductile irons. J. Heat Treating 3:310-325. https://doi.org/10.1007/BF02833125

14. Aurrekoetxea M, López de Lacalle LN, Llanos I Machining stresses and initial geometry on bulk residual stresses characterization by on-machine layer removal. Materials 13(6):1445. https://doi.org/10. 3390/ma13061445

15. Gutnichenko O, Bushlya V, Zhou J, Ståhl J-E (2017) Tool wear and machining dynamics when turning high chromium white cast iron with pcBN tools. Wear 390-391:253-269. https://doi.org/10.1016/ j.wear.2017.08.005

16. Abdoos M, Yamamoto K, Bose B, Fox-Rabinovich G, Veldhuis S (2019) Effect of coating thickness on the tool wear performance of low stress TiAlN PVD coating during turning of compacted graphite iron (CGI). Wear 422-423:128-136. https://doi.org/10.1016/j. wear.2019.01.062

17. Hägglund S (2013) Methods and models for cutting data optimization, doctoral thesis. Chalmers University of Technology, Gothenburg

18. Colding B (1981) The machining productivity mountain and its wall of optimum productivity, 9th NAMRAC, pp 37-42

19. Lindström B (1989) Cutting data field analysis and predictions Part 1: Straight Taylor Slopes. Ann CIRP 38:103-106

20. Johansson D, Hägglund S, Bushlya V, Ståhl JE (2017) Sensitivity of Colding tool life equation on the dimensions of experimental dataset. J. Superhard Mater. 39:271-281. https://doi.org/10.3103/ S1063457617040074

21. Ning J, Nguyen V, Huang Y, Hartwig KT, Liang SY (2018) Inverse determination of Johnson-Cook model constants of ultra-finegrained titanium based on chip formation model and iterative gradient search. Int J Adv Manuf Technol 99:1131-1140. https://doi. org/10.1007/s00170-018-2508-6

22. Ning J, Liang SY (2019) Predictive modeling of machining temperatures with force-temperature correlation using cutting mechanics and constitutive relation. Materials 12:284. https://doi.org/10. 3390/ma12020284

23. Ning J, Nguyen V, Liang SY (2019) Analytical modeling of machining forces of ultra-fine-grained titanium. Int J Adv Manuf Technol 101:627-636. https://doi.org/10.1007/s00170-018-2889-6

24. Vilches FJT, Hurtado LS, Fernandez FM, Gamboa CB (2017) Analysis of the chip geometry in dry machining of aeronautical aluminum alloys. Appl Sci 7:132. https://doi.org/10.3390/ app7020132

Publisher's note Springer Nature remains neutral with regard to jurisdictional claims in published maps and institutional affiliations. 